\title{
nature
}

14 March 2002 Volume 416 Issue no 6877

\section{Beyond the cloning debate}

Arguments over human embryonic stem cells and cloning have loomed large over the choice of a new director of the National Institutes of Health. But the expected nominee for the position will need to prove himself on other fronts.

W ithin the next month or two, the US Senate will vote on a bill that would ban research into therapeutic cloning - the creation of cloned human embryos to extract embryonic stem (ES) cells matched to individual patients. The result is too close to call, and lobbying for and against has reached fever pitch.

In this febrile atmosphere, unpublished scientific claims are assuming a weight usually afforded to peer-reviewed results (see Nature 415,$722 ; 2002)$. Last week, for instance, The Wall Street Journal discussed unpublished claims by Chinese researchers to have extracted ES cells from cloned embryos created by fusing human cells with rabbit eggs. Supporters of therapeutic cloning argued that other nations stand to reap the economic benefits if the United States turns its back on the field; opponents seized on the 'yuk' factor of combining human and animal material.

Even basic terminology is being reinvented. While the antiabortion lobby characterizes therapeutic cloning as 'clone and kill' medicine, the presidents of the National Academy of Sciences and the Institute of Medicine argue that 'therapeutic cloning' should be abandoned in favour of the phrase 'somatic cell nuclear transfer' (Science 295, 1237; 2002). The latter phrase is conceptually accurate, and in avoiding the word 'cloning' makes a clear distinction between reproductive cloning and the therapeutic procedure. But it hardly trips off the layperson's tongue, and may create the impression that scientists want to hide the fact that the procedure involves creating an embryo - albeit one consisting merely of a hollow ball of cells.
This is the background against which President George W. Bush is expected to announce this week that Elias Zerhouni, executive vice-dean of the Johns Hopkins University School of Medicine in Baltimore, Maryland, is his nominee for the post of director of the National Institutes of Health (NIH). Zerhouni was reportedly selected ahead of Tony Fauci, the widely tipped director of the National Institute of Allergy and Infectious Diseases (NIAID), because he was willing to endorse Bush's support for a ban on therapeutic cloning. Fauci, it is alleged, was insufficiently 'pro-life' to be trusted with the top NIH post.

Wisely, Zerhouni is keeping his own counsel. But when the time for his confirmation hearings in the Senate comes round, it is to be hoped that his position on ES-cell research and cloning does not dominate the discussion to the exclusion of all else.

Once US federal policy on cloning has been decided, Zerhouni's personal position will be moot. But the other issues facing the NIH will remain. Departed senior staff will still need to be replaced; debates about priorities in genome research will still need to be resolved; and the new director must develop a fruitful working relationship with Fauci so that the vast injection of funds into the NIAID for research into countering bioterrorism is wisely spent.

The senators who will debate Zerhouni's appointment should put his position on cloning to one side, and concentrate on examining how his experience at Johns Hopkins qualifies him to deal with the rest of the NIH's agenda.

\section{Helping hands for Arab science}

\section{A grassroots initiative to boost research in the Middle East deserves support - in particular from Arab Americans.}

L ater this month in Sharjah, in the United Arab Emirates, some 500 scientists from across the Arab world will hold what they hope will be a historic gathering. They will set research priorities for the Arab Science and Technology Foundation (ASTF), which aims to raise up to US\$150 million over five years to award peerreviewed grants to the region's scientists (see pages 120-122).

The foundation's leaders face an enormous task. Raising large sums of money is always hard, but raising the sum the ASTF has in mind, while retaining independence, will be doubly difficult. Not only have most Arab governments long neglected science, but many also distrust organizations over which they do not exert direct control.

The initial signs are encouraging. The ASTF has built itself from the bottom up, gathering together working scientists interested in strengthening research capacity across the region. It is committed to building links between Arab and Western labs; it has already raised some \$6million from the ruler of Sharjah, who has promised not to interfere with the running of the foundation; and it has secured an energetic cheerleader in Mohammed Aref, formerly science editor of the London-based Al Hayat newspaper, who several weeks ago visited Nature's London office and made a passionate case for the ASTF.

Western research agencies appear keen to build links with Arab scientists, and hopefully will work with the ASTF. But cooperation at the level of government agencies will remain vulnerable to the region's troubled politics - some of those planning to attend the Sharjah meeting, for instance, are coming from Iraq, a country that may soon be at war with the United States.

For this reason, the ASTF should also look to individual donations. Here, those of Arab descent living in the United States may prove useful. Particularly in the industrial Midwest, Arab Americans are an emerging economic and political force, courted by President George W. Bush in his 2001 election campaign. It is also worth noting that the scientist expected to be nominated by Bush for the post of director of the National Institutes of Health (see above) was born and educated in Algeria.

It may be a provocative example, but the Weizmann Institute of Science in Rehovot, Israel, hints at the potential. Around $17 \%$ of its annual budget of about $\$ 180$ million comes from donations, more than half being raised by the American Committee for the Weizmann Institute of Science - mostly from Jewish Americans. A tradition of scientific philanthropy isn't built overnight, but the ASTF has much to gain from convincing wealthy Arab Americans to rival their Jewish counterparts in their support of research. 